\title{
Anemia and heart failure: a cause of progression or only a consequence?
}

\author{
MARCO METRA, SAVINA NODARI, TANIA BORDONALI, SILVIA BUGATTI, BENEDETTA FONTANELLA, \\ CARLO LOMBARDI, ALBERTO SAPORETTI, GIULIA VERZURA, ROSSELLA DANESI, LIVIO DEI CAS
}

Section of Cardiovascular Diseases Department of Experimental and Applied Medicine, University of Brescia - Spedali Civili, Brescia - Italy

\begin{abstract}
Anemia is one of the most frequent co-morbidities in the patients with heart failure. Its prevalence increases from $4-7 \%$ in the subjects with asymptomatic left ventricular dysfunction to $>30 \%$ in the patients with severe heart failure. Renal insufficiency, activation of inflammatory mediators, and treatment with renin-angiotensin antagonists seem to be its main determinants. The results of many studies agree in showing that anemia is a powerful independent determinant of survival in patients with heart failure. However, the mechanisms of this relation are still incompletely understood. Moreover a favourable effect on prognosis of the correction of anemia has not been shown, yet, and also controlled studies assessing its effects on exercise tolerance have yielded controversial results. (Heart International 2007; 3: 1-11)
\end{abstract}

KEY WORDS: Anemia, Heart failure, Prognosis, Erythropoietin

\section{INTRODUCTION}

The introduction of renin-angiotensin-aldosterone antagonists, beta-blockers and cardiac resynchronization therapy has improved the prognosis of heart failure (HF). The improvement in the treatment of HF has been, however, attended by an increase of the importance of comorbidities as major determinants of prognosis of this syndrome. Among them, anemia is surely one of the most important.

\section{EPIDEMIOLOGY AND DEFINITIONS}

The prevalence of anemia in patients with $\mathrm{HF}$ ranges from $7 \%-10 \%$ to $70 \%-80 \%$ depending on differences in HF severity, demographic variables and comorbidities of the patients studied (1-3).

\section{Definitions}

There is not an universally recognized definition of anemia. The World Health Organization (WHO) defines anemia as a decrease in hemoglobin $(\mathrm{Hb})$ values below $13 \mathrm{gm} / \mathrm{dl}$ in men and $12 \mathrm{gm} / \mathrm{dl}$ in women (2). The National Kidney Foundation defines anemia as $\mathrm{Hb}$ values $<13.5 \mathrm{gm} / \mathrm{dl}$ in adult men and $<12 \mathrm{gm} / \mathrm{dl}$ in adult women (values based on the average of the lower quintile of the standard population ) (4).

In a retrospective analysis of the Studies of Left Ventricular Dysfunction (SOLVD), Al-Ahmad et al have shown that the prevalence of anemia could change from $22 \%$ to $4 \%$ according to differences in the hematocrit threshold value $(\leq 0.39 \%$, corresponding to serum hemoglobin of $13 \mathrm{gm} / \mathrm{dl}$ and $<0.35 \%$, corresponding to12 $\mathrm{gm} / \mathrm{dl}$, respectively) (5).

\section{Predisposing factors}

The prevalence of anemia increases with HF severity (5). Other parameters related to HF severity, such as left ventricular (LV) ejection fraction, blood pressure, BNP or NT-proBNP plasma concentrations, are associated to the prevalence of anemia $(1-3,6,7,10)$. Left ventricular ejection fraction (LVEF) has an inverse relationship with serum $\mathrm{Hb}$ levels and this relation is maintained also 
when patients with preserved left ventricular systolic function are included (7).

The prevalence of anemia also depends on the patients' demographic characteristics, since it is more frequent in the elderly, female and black patients $(8,9)$. Comorbidities, namely renal failure and diabetes, are frequently and independently related to anemia $(1-3,6,7$, 10).

\section{Recent onset anemia}

New onset anemia frequently develops during the clinical course of HF. The Carvedilol or Metoprolol European Trial (COMET) enrolled 3029 patients who were followed for 58 months. In this trial the incidence of recent onset anemia was of $14 \%$ at 1 year and $27.5 \%$ at 5 years. At multivariate analysis the predictive factors of recent onset anemia were age, high furosemide dose, increase of serum creatinine, hyponatremia, hyperkaliemia, and lack of aldosterone-antagonist administration (6). Another study had shown different predictive factors: low serum albumin, glomerular filtration rate, body weight, diastolic arterial pressure, an increase in furosemide dose, C-reactive protein, BNP levels and LVEF. These studies also showed that carvedilol (6) and valsartan (10) therapy, respectively, can be independent predictors of new onset anemia.

\section{MeCHANISMS}

The pathogenesis of anemia in patients with $\mathrm{HF}$ is multifactorial (Tab. I).

\section{Hemodilution}

Anemia is correlated to HF severity. Patients with HF often show signs of congestion. Water retention and increase in plasma volume can cause a "pseudo-anemia" due to hemodilution (11). Ritz et al showed that in 97 patients with HF the reduction of glomerular filtration, erythropoietin levels and expanded plasma volume were independent predictive factors of low $\mathrm{Hb}$ levels. Some studies, conducted using the radiolabeled albumin technique, have demonstrated that up to $46 \%$ of patients with HF and anemia have hemodilution along with a normal red blood cells number (12). Although a lower incidence of hemodilution has been reported in other studies, this mechanism should be excluded in anemic patients with HF (13). In these patients treatment should be diuretic therapy, while erythropoietin administration could further increase total blood volume with possible adverse clinical consequences (2).

There is a relevant percentage of anemic patients with HF but without hemodilution. In these patients, the cause is likely iron deficiency, chronic kidney disease, cachexia and angiotensin converting enzyme (ACE) inhibitors therapy.

\section{Iron deficiency}

The prevalence of iron deficiency in patients with $\mathrm{HF}$ is variable from $30 \%$ to $73 \%$ (13).

The higher percentage has been found in a study in which iron deficiency was measured also in the bone marrow. The inflammatory response in patients with HF leads to the reduction of iron absorption and anticoagulant and/or antiaggregant therapy could cause gastrointestinal bleeding. On the other hand, the iron resources in anemic patients with HF could be normal or high because of increased iron uptake and storage in macrophages (reticuloendothelial system) with a consequent reduction of its availability for hematopoiesis (14, 15). Intravenous iron therapy has been shown to increase serum $\mathrm{Hb}$ levels (from $11.2 \pm 0.7$ to $12.6 \pm 1.2 \mathrm{~g} / \mathrm{dl}$, $\mathrm{p}=0.0007$ ) as well as to improve exercise tolerance, quality of life and functional class (16). $\mathrm{B}_{12}$ and folate deficiency has not a significant role in pathogenesis of anemia in patients with HF (17).

TABLE I - MAIN FACTORS RELATED TO ANEMIA IN PATIENTS WITH HEART FAILURE

Demographic factors (age, gender, race)

Water and salt retention Iron deficiency

Renal failure

Chronic inflammatory activation

Concomitant treatment

- Angiotensin Converting Enzyme Inhibitors

- Angiotensin receptor blockers

- Non selective beta-blockers (carvedilol) 

of anemia in patients with heart failure.

Continuous lines show favourable effects. Outlines show inhibition mechanisms. The renal failure determines a reduced erythropoietin production. Citokines increase erythropoietin production but inhibit erythropoiesis with erythropoietin resistance, reduced iron availability and half life of red cells. Angiotensin converting enzyme inhibitors reduce renal production of erythropoietin by direct effects and increasing renal perfusion.
Fig. 1 - Pathogenetic mechanism

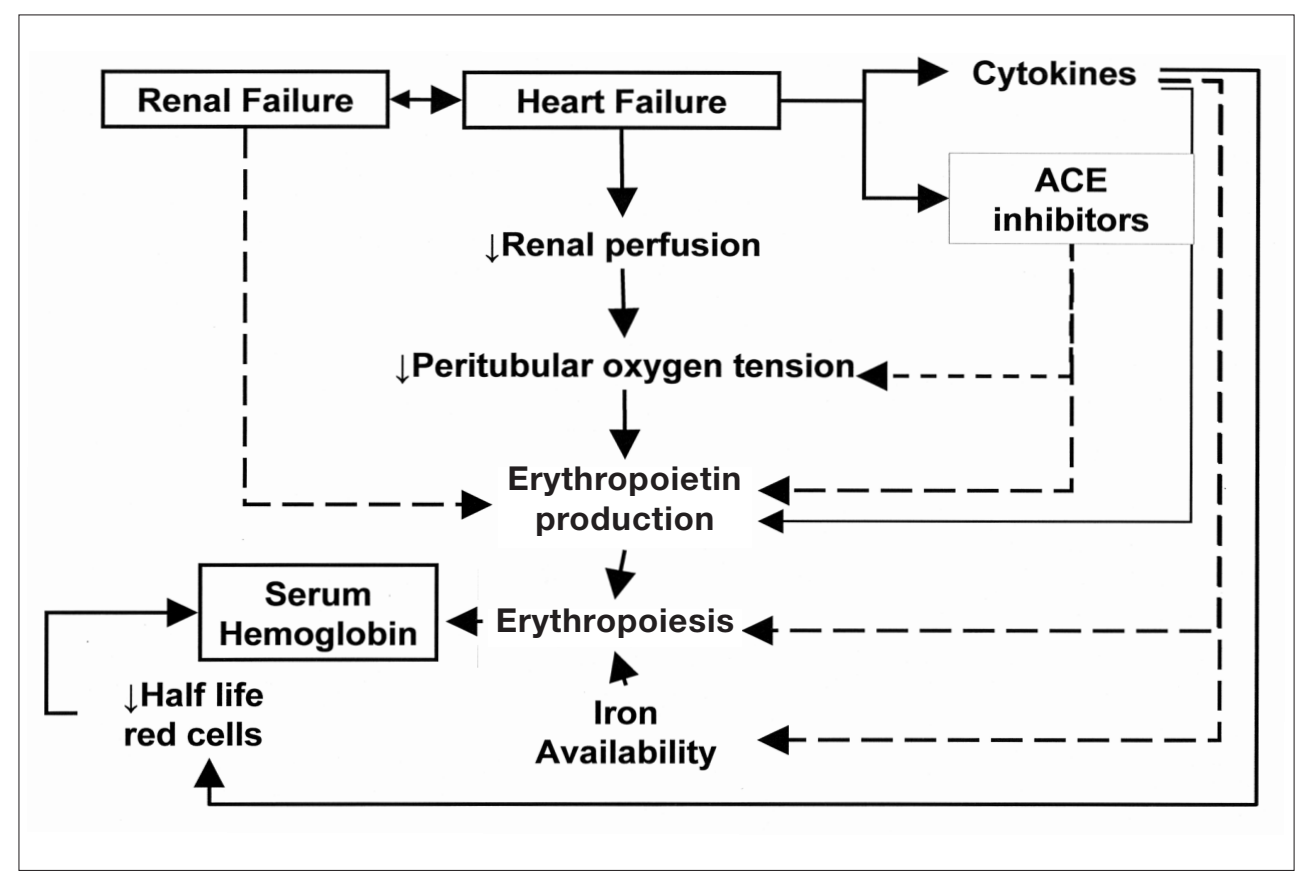

\section{Renal failure}

Moderate to severe chronic renal failure (glomerular filtration rate $<60 \mathrm{ml} / \mathrm{min}$ ) is one of the main determinants of anemia $(1,2,5,17,18)$. In $30 \%-40 \%$ of patients with $\mathrm{HF}$ an inverse correlation between serum creatinine and plasmatic $\mathrm{Hb}$ has been reported. Chronic kidney disease causes anemia through a reduction in erythropoietin production, although patients with $\mathrm{HF}$ can show increased levels of erythropoietin (18-20). The main cause of anemia in HF, similarly to other chronic diseases associated to inflammatory processes, is resistance to erythropoietin effects rather than its reduced production (14).

\section{Cytokines}

Reduced body mass and cardiac cachexia have been shown to be important predictive factors for anemia in patients with $\operatorname{HF}(2,6,7)$. The activation of pro-inflammatory cytokines (TNF- $\alpha$, interleukine- 6 , interleukine10 , interferon- $\gamma$, lipopolysaccharides) is important for both anemia and cardiac cachexia pathogenesis. Proinflammatory cytokines could have many effects: stimulation of erythropoietin, inhibition of gut iron absorption, inhibition of the proliferation of progenitor red cells, increased apoptosis, red cells damage, increased ery- throphagocitosis, increased uptakes and storage of iron into macrophages, resistance to erythropoietin. All these effects may ultimately lead to reduced erythropoiesis (Fig. 1, Tab. II) (21). Chronic inflammation causes reduced iron availability, that is stored by macrophages of the reticuloendothelial system $(22,23)$.

\section{Concomitant therapy}

Neuro-hormonal antagonist and, namely, ACE-inhibitors and angiotensin II receptors blockers are important causes of anemia in patients with HF. An analysis of the SOLVD study has shown that enalapril is an independent predictive factor for low Hb levels (23). The Valsartan Heart Failure (VAlHeFT) trial has confirmed these data for angiotensin II receptors blockers (10). Angiotensin II increases erythropoietin secretion through hypoperfusion and renal hypoxia and, thus, can directly stimulate erythropoiesis (24). Antagonists of renin-angiotensin system, blocking the effects of angiotensin II, also reduce erythropoiesis. Moreover, ACE catalyzes the demolition of $\mathrm{N}$-Acetil-seril-lisil-proline (Ac-SKPD), a tetra peptide inhibitor of the proliferation of haematopoietic stem cells. ACE inhibitor administration causes an increase in the plasmatic concentrations of this substance with a consequent development of anemia (25). 
TABLE II - EFFECTS OF CYTOKINES ON IRON METABOLISM AND ERYTHROPOIESIS

\begin{tabular}{|c|c|c|}
\hline Cause & Mechanism & Effects \\
\hline$\uparrow$ TNF- $\alpha$, IF- $\gamma$, IL-1 & $\begin{array}{l}\downarrow \text { proliferation and differentiation } \uparrow \text { progenitors cells apoptosis; } \\
\text { toxic effects induced by free radicals; } \\
\downarrow \text { erythropoietin receptor expression }\end{array}$ & $\begin{array}{l}\text { erythropoietin resistance; } \\
\downarrow \text { erythropoiesis }\end{array}$ \\
\hline $\begin{array}{l}\uparrow \text { TNF- } \alpha, \text { IL-6, IF- } \gamma \text {, } \\
\text { LPS, IL-10 }\end{array}$ & $\uparrow$ ferritin transcription & $\uparrow$ ferritin \\
\hline $\begin{array}{l}\text { TNF- } \alpha, \text { IL-6, IF- } \gamma \\
\text { LPS, IL-10 }\end{array}$ & $\begin{array}{l}\text { Red cells damage (free radicals?) } \uparrow \text { red cells fagocitosis } \\
\text { by macrophages }\end{array}$ & $\begin{array}{l}\downarrow \text { half life red cells } \\
\uparrow \text { storage and iron retention } \\
\text { in macrophage } \\
\downarrow \text { sideremy }\end{array}$ \\
\hline IL-6 & $\uparrow$ Epcidin: $\downarrow$ iron enteric uptake & $\downarrow$ sideremy \\
\hline IF- $\gamma$, LPS & $\uparrow$ Divalent Metal transporter 1 (DIMT 1), $\downarrow$ ferroportin & $\begin{array}{l}\downarrow \text { sideremy, } \downarrow \text { iron availability } \\
\text { for progenitor cells }\end{array}$ \\
\hline
\end{tabular}

TNF= Tumor Necrosis Factor; IF = interferon; IL = interleukin; LPS= lipopolysaccharides $(2,14)$.

Differences between beta-blockers may also be important. An analysis of the Carvedilol or Metoprolol European Trial (COMET) has shown that carvedilol therapy is associated with a slight but significant $\mathrm{Hb}$ decrease $(0.2 \mathrm{~g} / \mathrm{dl})$ compared to metoprolol therapy (6). Renal cells secreting erythropoietin or progenitor red cells have sympathetic innervation with beta-1, beta-2, and alpha adrenergic receptors (26). Beta-2 receptors have the most important role and carvedilol could cause a decrease in $\mathrm{Hb}$ levels through its non selective action on beta-2 andrenergic receptors.

\section{ANEMIA AND CLINICAL OUTCOMES}

Many retrospective analyses of clinical trials have shown that reduced $\mathrm{Hb}$ levels are independently associated with an increased risk of hospitalisation and mortality in patients with HF (1-3, 5-10, 12, 27-30). A recent re-analysis of SOLVD trial shows that anemia is also an independent risk factor related to new onset kidney disease (31). Some studies have demonstrated that anamia was an independent predictor for HF mortality but not for sudden cardiac death $(6,9)$. Anemia is associated with poor outcome not only in patients with LV systolic dysfunction, but also in patients with asymptomatic LV dysfunction $(5,32)$ or with preserved $\operatorname{LVEF}(7,30)$.
There is a linear relationship between reduced $\mathrm{Hb}$ serum levels and increased mortality risk: a 1-mg/dl decrease $\mathrm{Hb}$ levels has been associated to an increase in mortality of $13 \%$ (relative risk [RR], 1.13; 95\% confidence interval [95\% IC], 1.045-1.224) (2). Low Hb levels are related to severe prognosis but it is yet unclear the effect of an increased $\mathrm{Hb}$ serum level. There is usually a linear relationship between high $\mathrm{Hb}$ levels and reduced mortality and morbidity risk. However, Sharma et al in the "Evaluation of Losartan in the Elderly II" (ELITE II) trial showed a $\mathrm{U}$-shaped relation between $\mathrm{Hb}$ concentration and mortality risk. A minimum mortality risk was shown for physiological serum values (13 e $15 \mathrm{~g} / \mathrm{dl}$ ) while a major mortality rate was demonstrated for serum values $>15 \mathrm{~g} / \mathrm{dl}$ (28). Go et al in 59772 patients with HF (3) showed an increased mortality risk with $\mathrm{Hb}$ levels $>17 \mathrm{~g} / \mathrm{dl}$ (Fig. 2). However, other comorbidities (such as chronic obstructive pulmonary disease, COPD) could have influenced the outcome, especially in the elderly patients.

Changes in $\mathrm{Hb}$ levels during the clinical course of $\mathrm{HF}$ could influence the prognosis. Results from COMET trial have shown that patients with a 2-3 g/dl decrease in serum $\mathrm{Hb}$ have an increased mortality risk of $47 \%$ (RR, 1.466; 95\%IC, 1.092-1.969; $p=0.0109$ ), while a Hb reduction $\geq 3 \mathrm{~g} / \mathrm{dl}$ was associated to a three fold greater mortality rate (RR, 3.37; IC95\%, 2.464-4.611; $\mathrm{p}<0.0001)$ (6). 


\section{Mechanisms (Tab. III)}

Myocardial Hypertrophy. Anemia is strictly related to cardiac hypertrophy $(33,34)$. These evidences have been confirmed in an analysis of "The Randomized Etanecerpt North American Strategy to Study Antagonism of Cytokines (RENAISSANCE) Trial" (31). In 66 patients the $\mathrm{Hb}$ values were related to the LV myocardial mass assessed by magnetic resonance imaging (MRI) after six-months follow-up. LV myocardial index (LVMI) increased by $+1.6 \pm 7.9 \mathrm{~g} / \mathrm{m}^{2}$ in patients with stable o decreased $\mathrm{Hb}$ values while it decreased by $-7.5 \pm 12.1 \mathrm{~g} / \mathrm{m}^{2}$ in patients with increased serum Hb level $(p=0.0008)$. An inverse correlation was observed between changes in $\mathrm{Hb}$ levels and LVMI changes ( $r=0.32, \mathrm{P}=0.0086)(31)$. However, other clinical trials did not find any relationship between changes in serum $\mathrm{Hb}$ values and LV myocardial mass and no favourable effect of increased $\mathrm{Hb}$ levels on cardiac structure and function have been shown, to date (35-39).

Oxygen uptake in peripheral tissues. The decreased availability of oxygen substrates to the peripheral tissues represents another untoward effect of anemia. In patients with anemia and HF the reduced cardiac output can not compensate the reduced $\mathrm{Hb}$ levels and this could explain the more severe symptoms of anaemic patients, with a more severe impairment in exercise capacity and a greater risk of rehospitalisation (8). A positive correlation has been shown between peak $\mathrm{VO}_{2}$ and serum $\mathrm{Hb}$ values $(40,41)$. The administration of erythropoiesis stimulating agents (ESA) has been related to an improvement in exercise capacity either in patients with renal failure (42) or in patients with $\operatorname{HF}(16,43,44)$.

The reduced peripheral oxygen demand can lead to an increased cardiac work with a consequent myocardial ischaemia and LV remodelling increasing mortality and cardiovascular hospitalisation $(2,3)$.

Other Mechanisms. Anemia causes neurohormonal activation, oxidative stress and reduced nitric oxide production (30). It may also cause salt and water retention and peripheral edema with consequent poor prognosis in patients with HF (2).

Anemia can also be considered a consequence of HF severity. Its exact role in HF must, however, be shown by controlled trials showing an improvement in survival with anemia correction.

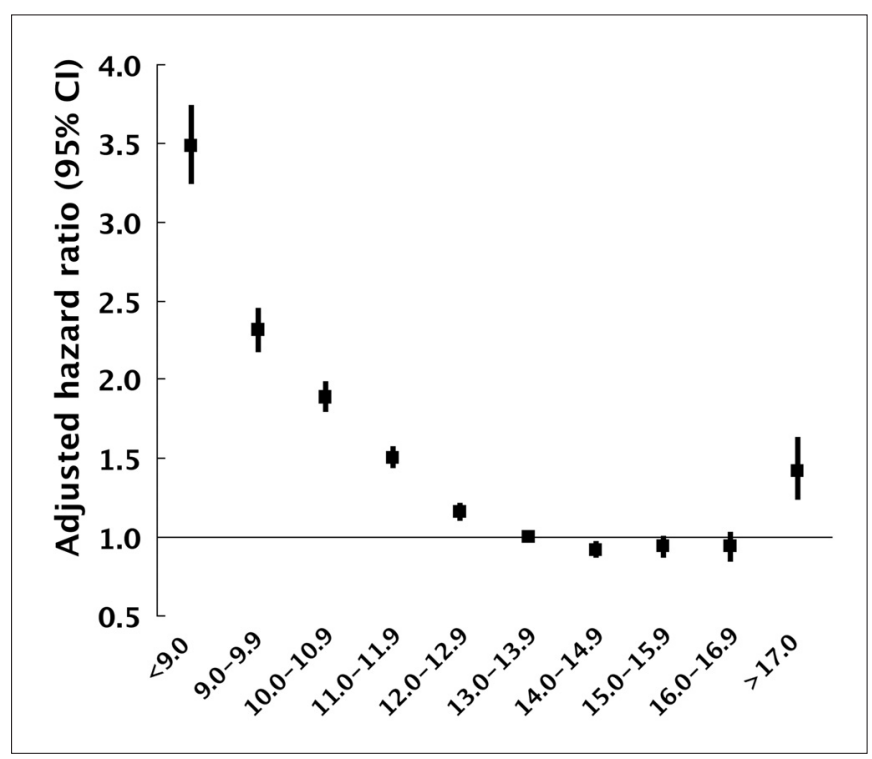

Fig. 2 - J-shaped relation between the serum hemoglobin levels and mortality risk in 59, 772 patients with heart failure (3).

TABLE III - NEGATIVE EFFECTS OF ANEMIA ON OUTCOME IN PATIENTS WITH HEART FAILURE

Myocardial hypertrophy
Reduced oxygen uptake in peripheral tissues
- Increased cardiac output

Neuro-hormonal activation

Worsening renal failure

Edema and fluid retention induction

\section{TREATMENT APPROACHES}

Hemotransfusion. According to the American Guidelines, blood transfusion is recommended for $\mathrm{Hb}$ levels in the range from 6 to $8 \mathrm{~g} / \mathrm{dl}$. The clinical utility of hemotransfusion for higher $\mathrm{Hb}$ levels is still unsettled. Generally, hemotransfusion is not considered for $\mathrm{Hb}$ values $>10 \mathrm{~g} / \mathrm{dl}(45)$.

In 78, 974 elderly patients hospitalised with acute myocardial infarction, blood transfusion was associated with a lower mortality rate at 30 days in patients with an hematocrit $<30 \%$ on admission (46). Conversely, in 838 patients $(26 \%$ with cardiovascular disease), stable $\mathrm{Hb}$ levels between 10-12 $\mathrm{g} / \mathrm{dl}$ did not provide additional 
benefits on mortality compared with $\mathrm{Hb}$ concentration of 7-9 $\mathrm{g} / \mathrm{dl}(47)$.

Moreover, the blood transfusion may be associated with some adverse effects such as immunosuppression, increased infection risk, iron overload and the sensitization to HLA antigens (48). Transfusion may be considered only an acute phase treatment for severe anemia and it is not available as a long-term therapeutic strategy.

Iron therapy. It is commonly accepted that patients with chronic HF have relative iron deficiency $(2,22)$. Total body iron content may be normal. However, HF, like other chronic inflammatory diseases, is associated to increased uptake and storage of iron within the reticuloendothelial system $(11,14)$. Thus, less iron is available for erythropoiesis despite possibly increased total body iron stores (so called "reticulo-endothelial block").

Several small studies have demonstrated that iron therapy may cause a slight but significant increase in serum $\mathrm{Hb}$ levels and improve symptoms and exercise tolerance $(16,49)$. The IRON-HF study is an ongoing trial designed to assess the clinical impact of iron supplementation (intravenous or oral administration), compared to placebo, in patients with HF and low serum iron and transferrin concentrations (50).

Iron therapy is also used in association with ESA. Current guidelines from the National Kidney Foundation recommend the use of intravenous iron (because of the reduced enteric absorption) to maintain serum ferritin levels of 100 to $800 \mathrm{ng} / \mathrm{ml}$ and a transferrin saturation of $20 \%$ to $50 \%$ in order to optimize the response to ESA (4).

It must be, however, pointed out that high doses iron therapy has severe side effects such as an increased oxydative stress with endothelial dysfunction and atherosclerosis progression (51).

\section{Erythropoiesis stimulating agents (ESA)}

An increased level of serum erythropoietin can occur in patients with $\mathrm{HF}$ and is correlated to a more severe outcome $(18,19)$. However, erythropoietin levels of HF patients with anemia are lower, compared to patients with similar $\mathrm{Hb}$ levels without HF. In addition, HF, like other chronic inflammatory diseases, is associated to peripheral resistance to erythropoietin actions $(11,22$, 53). This is mainly caused by the neurohormonal and inflammatory activation. ACE inhibitor therapy may also play a role $(23,24)$. These observations suggest an im- portant role for therapy with ESA, associated with iron supplementation, in patients with anemia and HF.

Available agents. There are three currently available ESA for the treatment of anemia: epoetin- $\alpha$, epoetin- $\beta$ (both of which are recombinant human erythropoietins, rHuEpo) and darbepoetin- $\alpha$ (analog of human erythropoietin). These agents can be administered either intravenously or subcutaneously. Plasma half-life of epoetin$\alpha$ and epoetin- $\beta$ after intravenous dosing is 6 to 8 hours. After subcutaneous administration, the plasma half-life is increased to more of 24 hours. Thus, epoetin- $\alpha$ and epoetin- $\beta$ should be administered subcutaneously once to three times a week. Darbepoetin- $\alpha$ has a stronger affinity for erythropoietin receptors with a longer plasma half-life (approximately 48 hours), and, hence, longer dosing intervals ( 1 to 2 weeks) may be used during maintenance therapy $(2,4)$.

Clinical efficacy. The effect of rHuEpo treatment in anaemic patients with HF was first reported by Silveberg et al in 2000 (52). Twenty-six anemic patients with advanced $\mathrm{HF}$ and serum $\mathrm{Hb}<12 \mathrm{~g} / \mathrm{dl}$ were treated with subcutaneous rHuEpo and intravenous iron sucrose. After 6-7 months of treatment with rHuEpo, mean $\mathrm{Hb}$ levels increased from $10.2 \mathrm{~g} / \mathrm{dl}$ to $12.1 \mathrm{~g} / \mathrm{dl}$, with an improvement in New York Heart Association (NYHA) functional class, LVEF (from $28 \pm 5 \%$ to $35 \pm 8 \%, p<0.001$ ), decreased needs for intravenous furosemide and a decreased hospitalisation rate (54). The same investigators reported a significant reduction in hospitalisations and days of hospitalisation in another randomised open label trial in 32 patients (53).

Mancini et al conduced a single-blind, randomised, placebo-controlled trial of rHuEpo therapy in 26 patients with advanced HF and anemia (hematocrit <35\%) (43). Patients received 5000 Units of subcutaneous rHuEpo three times per week and supplemental oral iron and folate, adjusted to raise hematocrit to $>45 \%$. Compared with the placebo group, rHuEpo therapy was associated with significant increase in $\mathrm{Hb}$ values from $11.0 \pm 0.5$ to $14.3 \pm 1.0 \mathrm{~g} / \mathrm{dl}$, with a concomitant increase in treadmill exercise duration and peak oxygen uptake $(11.0 \pm 1.8$ to $12.7 \pm 2.8 \mathrm{ml} / \mathrm{min}$ per kilogram, $\mathrm{p}<0.05)$. Increases in serum $\mathrm{Hb}$ levels were linearly related to peak oxygen uptake changes.

Another more recent study conducted in Italy confirmed the clinical benefits of rHuEpo therapy. Forty patients with severe HF were randomised to receive, in a 
double blind fashion, either subcutaneous rHuEpo for three months twice a week, or placebo (saline solution). The treated group showed a significant increase in $\mathrm{Hb}$ values (from $10.4 \pm 0.6$ to $12.4 \pm 0.8 \mathrm{~g} / \mathrm{dl}, \mathrm{p}<0.01$ ), an improvement in NYHA functional class (from $3.5 \pm 0.6$ to $2.8 \pm 0.5, p<0.05)$, and an increase in peak oxygen consumption (from $12.8 \pm 2.8$ to $15.1 \pm 2.8 \mathrm{ml} / \mathrm{Kg}$ per minute, $\mathrm{p}<0.05$ ). There was also a fall in plasma BNP levels, a reduction in serum creatinine and an increase in estimated creatinine clearance (54).

Studies with Darbepoetin- $\underline{\alpha}$. In a randomized, placebo-controlled trial in 41 patients with HF and anemia, darbepoetin- $\alpha$ administration, once every 2 weeks for 26 weeks, was associated with an increase in serum $\mathrm{Hb}$ values from $11.8 \pm 0.2$ to $13.9 \pm 0.4 \mathrm{~g} / \mathrm{dl}$ (versus $11.6 \pm 0.2$ to $12.3 \pm 0.4 \mathrm{~g} / \mathrm{dl}$ in the placebo group). Darbepoetin- $\alpha$ administration was also associated to an improvement in quality of life, evaluated by the patients' Global Assessment score. However, the Kansas City Cardiomyopathy and the Minnesota Living with Heart Failure scores, exercise duration and peak $\mathrm{VO}_{2}$ did not show any significant change compared to placebo. Peak $\mathrm{VO}_{2}$ increased by $0.5 \mathrm{ml} / \mathrm{Kg} / \mathrm{min}$ in the darbepoetin- $\alpha$ group, versus $+0.1 \mathrm{ml} / \mathrm{Kg} / \mathrm{min}$ in the placebo group $(p=0.40)$. No significant correlation between $\mathrm{Hb}$ concentrations and exercise tolerance was shown (44).

Although the results of this trial may have been caused by chance, they may also suggest that a more rigorous approach, with double-blind placebo control, allowed a more accurate assessment of the real effects of therapy with ESA on quality of life and exercise tolerance, compared to previous studies (43). It might also be that the number of patients studied was insufficient to reach statistical significance. In the MIRACLE trial (Multicenter InSync Randomized Clinical Evaluation) enrolment of 369 patients was necessary to show a significant improvement in exercise tolerance with CRT versus control (55).

A recent combined analysis of two randomised double-blind, placebo-controlled trials comparing darbepoetin- $\alpha$ versus placebo in 475 patients did not show any improvement in NYHA class and Quality of Life with darbepoetin- $\alpha$. This study also showed a trend to a decrease in the risk of composite outcome (death or HF hospitalization) and mortality in the darbepoetin- $\alpha$ group versus placebo group $(39 / 266,15 \%$ vs $46 / 209$, $22 \%$; HR $0.67,95 \% \mathrm{Cl} 0.44-1.03, \mathrm{p}=0.06$ ) with also a tendency to a lower mortality in the darbepoetin- $\alpha$ group $(6 \%$ vs $9 \%$; HR, 0.76) $(49,56)$.

A large-scale, mortality trial on 3400 patients with anemia and HF (Reduction of Events with Darbepoetin$\alpha$ in Heart Failure, RED-HF) is ongoing and will likely definitively show the effects of darbepoetin- $\alpha$ on outcome in these patients (56).

Optimal target level of $\mathrm{Hb}$. In November 2006, two large-scale, controlled studies with ESA in patients with chronic kidney disease (CKD) were published (Correction of Hemoglobinand Outcomes in Renal Insufficiency [CHOIR] and Cardiovascular Risk reduction by Early Anemia Treatment with Epoetin beta [CREATE]) $(57,58)$. Both these studies were prematurely stopped because of a tendency to a worse outcome in the ESA treated patients $(59,60)$. In CHOIR, 1432 patients with anemia and renal insufficiency ( $23 \%$ patients with a history of $\mathrm{HF}$ ), were treated with two different erythropoietin regimes to reach $\mathrm{Hb}$ target levels of $13.5 \mathrm{~g} / \mathrm{dl}$ or 11.3 $\mathrm{g} / \mathrm{dl}$. During a median follow-up of 16 months, the higher $\mathrm{Hb}$ target group had an increase in the composite endpoint of death, myocardial infarction, HF hospitalisation and stroke (HR, 1.34; $p=0.03)$. There was also a tendency to an increased risk of the composite end point of death or nonfatal myocardial infarction in the group assigned to a higher hematocrit $(\mathrm{HR}, 1.3 ; 95 \% \mathrm{Cl}$ 0.9-1.9) (61).

Differently, in CREATE study (57) (603 patients with anemia and renal failure, $33 \%$ with HF), there was not an increase in cardiovascular events in the patients assigned to reach the target $\mathrm{Hb}$ levels after epoietin- $\beta$ treatment $(13.0-15.0 \mathrm{gm} / \mathrm{dl})$. However, the number of patients requiring haemodialysis and with high blood pressure values was greater in the group assigned to higher target $\mathrm{Hb}$ values (13 vs 23 ). Similar results were obtained in another study in diabetic patients $(38,58)$.

A tendency to an increase in the risk of death was shown by preliminary results of two studies in patients with cancer and anemia.

On the basis of these results, on 9 march 2007, the Food and Drug Administration (FDA) recommended to avoid the achievement of $\mathrm{Hb}$ levels $>12 \mathrm{~g} / \mathrm{dl}$ and to stop erythropoietin therapy when these are $>12 \mathrm{~g} / \mathrm{dl}$. The administration of low doses of ESA are still recommended with $\mathrm{Hb}$ values $<10 \mathrm{~g} / \mathrm{dl}(60)$. The National Kidney Foundation recommends to achieve a serum $\mathrm{Hb}$ value of 11$12 \mathrm{~g} / \mathrm{dl}(4,60)$. 
Adverse effects of ESA administration. The increased cardiovascular events rates in patients with high level of $\mathrm{Hb}$ after ESA therapy may be due to increased blood viscosity and high blood pressure (59).

The increased blood viscosity associated with high hematocrit in patients with diffuse atherosclerosis and kidney disease, increases thrombotic events. Direct effect of erythropoietin on platelets and endothelium increases the thrombotic risk (62). These evidences are not confirmed in patients with HF because the frequent concomitant therapy with antiplatelet and anticoagulant medications may reduce prothrombotic effects of erythropoietic agents. To confirm these data, large trials with long-term follow up are necessary $(49,59)$.

ESA therapy causes an increased blood pressure by increased blood viscosity, activation of the neurohormonal system, and direct effects on microvascular structure and function. However, blood pressure was significantly increased only in a single study (58) and in patients with HF no changes in blood pressure or in peripheral resistances have been observed after erythropoietin therapy (60).

\section{RECOMMENDATIONS AND FUTURE DIRECTIONS}

The role of anemia as an independent prognostic factor is now well known. Anemia is frequent in patients with advanced HF and its aetiology is generally multifactorial. It is not only related with impaired renal perfusion and kidney failure, but also it could be triggered by an inflammatory and neurohormonal activation and/or by renin angiotensin system therapy. The prognostic value of anemia is not clear and there are no evidences about the correction of low $\mathrm{Hb}$ values and improving survival rate in patients with HF.

The administation of erithropoietic stimulating agents remains the more effective therapy to improve $\mathrm{Hb}$ serum level. According to the 2005 Guidelines about the diagnosis and treatment of chronic HF of the European Society of Cardiology (ESC), anemia is a risk factor for worsening $\mathrm{Hf}$ but the treatment is not defined (63). According to the 2005 Guidelines of American Heart Association (AHA)/American College of Cardiology (ACC), benefits of ESA therapy in anaemic patients with HF has not been shown, yet, (class IIB recommendation, level of evidence C) (64). The treatment with ESA is common- ly considered effective only in patients with kidney diseases (4).

In $\mathrm{HF}$ patients with moderate-to-severe anemia $(\mathrm{Hb}$ $<11 \mathrm{~g} / \mathrm{dl}$ ), current guidelines of FDA and of National Kidney Foundation recommend treatment with ESA to reach $\mathrm{Hb}$ target value of $10-12 \mathrm{~g} / \mathrm{dl}$ and improve the quality of life. However, there are no clinical data supporting the use of ESA to improve the outcome in HF patients. Large trials with long term follow up are needed to determine the effects on morbidity and mortality (59).

ESA may have antiapoptotic and antischaemic effects with a pro-angiogenic activity on endothelial cells (3, 65-68). Cytoprotective and antiapoptotic effects have been shown $(69,70)$ as well as a beneficial action on central nervous system injury and in experimental models of myocardial hypoxia. These evidences showed the possibility that derivatives of rHuEpo may be useful to protect cardiomyocites by ischaemic injury and to improve the myocardial function in patients with $\mathrm{HF}$, rather than reducing other co-morbidities.

Address for correspondence:

Prof. Marco Metra

Section of Cardiovascular Diseases

Dept. Of Experimental and Applied Medicine

University of Brescia c/o Spedali Civili

P.zza Spedali Civili, 1

25123 Brescia - Italy

metramarco@libero.it 


\section{REFERENCES}

1. Felker GM, Adams KF Jr, Gattis WA, O'Connor CM. Anemia as a risk factor and therapeutic target in heart failure. J Am Coll Cardiol 2004; 44: 959-66.

2. Yi-Da Tang, Katz SD. Anemia in chronic heart failure. Circulation 2006;113: 2454-2461..

3. Go AS, Yang J, Ackerson LM, Lepper K, Robbins S, Massie BM, Shlipak MG. Hemoglobin level, chronic kidney disease, and the risks of death and hospitalization in adults with chronic heart failure: the Anemia in Chronic Heart Failure: Outcomes and Resource Utilization (ANCHOR) Study. Circulation 2006; 113: 2713-23.

4. KDOQI; National Kidney Foundation. KDOQI Clinical Practice Guidelines and Clinical Practice Recommendations for Anemia in Chronic Kidney Disease. Am J Kidney Dis 2006; 47(5 Suppl 3): S11-145.

5. Al-Ahmad A, Rand WM, Manjunath G, et al. Reduced kidney function and anemia as risk factors for mortality in patients with left ventricular dysfunction. J Am Coll Cardiol 2001; 38: 955-62.

6. Komajda M, Anker SD, Charleswoth A, et al. The impact of new onset anemia on morbidity and mortality in chronic heart failure: results from COMET. Eur Heart J 2006; 27 : 1440-6.

7. O'Meara E, Clayton T, McEntegart MB, et al. Clinical correlates and consequences of anemia in a broad spectrum of patients with heart failure: results of the Candesartan in Heart Failure: Assessment of Reduction in Mortality and Morbidity (CHARM) Program. Circulation 2006; 113: 98694.

8. Horwich TB, Fonarow GC, Hamilton MA, MacLeallan WR, Borenstein J. Anemia is associated with worse symptoms, greater impairment in functional capacity and significant increase in mortality in patients with advanced heart failure. J Am Coll Cardiol 2002; 39: 1780-6.

9. Mozaffarian D, Nye R, Levy WC. Anemia predicts mortality in severe heart failure: The prospective randomized amlodipine survival evaluation (PRAISE). J Am Coll Cardiol 2004; 93: 1055-7.

10. Anand IS, Kuskoski MA, Rector T, et al. Anemia and change in hemoglobin over time related to mortality and morbidity in patients with chronic heart failure: results from Val-HeFT. Circulation 2005; 112: 1121-7.

11. Westenbrink BD, Visser FW, Voors AA, et al. Anemia in chronic heart failure is not only related to impaired renal perfusion and blunted erythropoietin production, but to fluid retention as well. Eur Heart J 2007; 28: 166-71.

12. Androne AS, Katz SD, Lund L, LaManca J, Hudaihed A, Hryniewicz K, Mancini DM. Hemodilution is common in patients with advanced heart failure. Circulation 2003; 107: $226-9$
13. Nanas JN, Matsouka C, Karageorgopoulos D, et al. Etiology of anemia in patients with advanced heart failure. $J$ Am Coll Cardiol 2006; 48: 2485-9.

14. Weiss G, Goodnough LT. Anemia of chronic disease. N Engl J Med 2005; 352: 1011-23.

15. Westenbrink BD, Voors AA, van Veldhuisen DJ. Is anemia in chronic heart failure caused by iron deficiency? J Am Coll Cardiol 2007; 49: 2301-2.

16. Bolger AP, Bartlett FR, Penston HS, et al. Intravenous iron alone for the treatment of anemia in patients with chronic heart failure. J Am Coll Cardiol 2006; 48: 1225-7.

17. DeSilva R, Rigby AS, Klaus KA, et al. Anemia, renal dysfunction and their interaction in patients with chronic heart failure. Am J Cardiol 2006; 98: 391-8.

18. Volpe M, Tritto C, Testa U, et al. Blood levels of erythropoietin in congestive heart failure and correlation with clinical, hemodynamic, and hormonal profiles. Am J Cardiol 1994; 74: 468-73.

19. van der Meer P, Voors AA, Lipsic E, Smilde TD, van Gilst $\mathrm{WH}$, van Veldhuisen DJ.Prognostic value of plasma erythropoietin on mortality in patients with chronic heart failure. J Am Coll Cardiol 2004; 44: 63-7.

20. George J, Patal S, Wexler D, et al. Circulating erythropoietin levels and prognosis in patients with congestive heart failure: comparison with neurohormonal and inflammatory markers. Arch Intern Med 2005;165:1304-9.

21. Opasich C, Cazzola M, Scelsi L, et al. Blunted erythropoietin production and defective iron supply for erythropoiesis as major causes of anaemia in patients with chronic heart failure. Eur Heart J 2005; 26: 2232-7.

22. MacDougall IC, Cooper AC. Erytropoietin resistance: the role of inflammation and pro-inflammatory cytokines. Nephrol Dial Transplant 2002; 17(suppl11): 39-43.

23. Ishani A, Weinhandl E, Zhao Z, et al. Angiotensin-converting enzyme inhibitor as a risk factor for the development of anemia, and the impact of incident anemia on mortality in patients with left ventricular dysfunction. J Am Coll Cardiol 2005; 45: 391-9.

24. Mrug M, Stopka T, Julian BA, Prchal JF, Prchal JT.Angiotensin II stimulates proliferation of normal early erythroid progenitors. J Clin Invest 1997; 100: 2310-4.

25. van der Meer P, Lipsic E, Westenbrink BD, et al. Levels of hematopoiesis inhibitor $\mathrm{N}$-acetyl-seryl-aspartyl-lysylproline partially explain the occurrence of anemia in heart failure. Circulation 2005; 112: 1743-7.

26. Mladenovic J, Adamson JW. Adrenergic modulation of erythropoiesis: in vitro studies of colony-forming cells in normal and polycythaemic man. Br J Haematol 1984; 56: 323-32.

27. Sharma R, Francis DP, Pitt B, Poole-Wilson PA, Coats AJS, Anker SD. Haemoglobin predicts survival in patients with chronic heart failure: a substudy of the ELITE II trial. Eur Heart J 2004; 25: 1021-8. 
28. Ezekowitz JA, McAlister FA, Armstrong PW. Anemia is common in heart failure and is associated with poor outcomes: insights from a cohort of 12065 patients with new-onset heart failure. Circulation 2003; 107: 223-5.

29. Brucks S, Little WC, Chao T, Rideman RL, Upadhya B, Wesley-Farrington D, Sane DC. Relation of anemia to diastolic heart failure and the effect on outcome. Am J Cardiol 2004; 93: 1055-7.

30. Anand I, McMurray JJ, Whitmore J, Warren M, Pham A, McCamish MA, Burton PB. Anemia and its relationship to clinical outcome in heart failure. Circulation 2004; 110: 149-54.

31. Bansal N, Tighiouart H, Weiner D, Griffith J, Vlagopoulos P, Salem D, Levin A, Sarnak MJ. Anemia as a risk factor for kidney function decline in individuals with heart failure. Am J Cardiol 2007; 99: 1137-42.

32. Valeur N, Nielsen OW, McMurray JJ, Torp-Pedersen C, Kober L; TRACE Study Group. Anaemia is an independent predictor of mortality in patients with left ventricular systolic dysfunction following acute myocardial infarction. Eur J Heart Fail 2006; 8: 577-84.

33. Rakusan K, Cicutti N, Kolar F. Effect of anemia on cardiac function, microvascular structure, and capillary hematocrit in rat hearts. Am J Physiol Heart Circ Physiol 2001; 280: H1407-14.

34. Levin A, Thompson CR, Ethier J, et al. Left ventricular mass index increase in early renal disease: impact of decline in hemoglobin. Am J Kidney Dis 1999; 34: 125-34

35. Parfrey PS, Foley RN, Wittreich BH, Sullivan DJ, Zagari MJ, Frei D. Double-blind comparison of full and partial anemia correction in incident hemodialysis patients without symptomatic heart disease. J Am Soc Nephrol 2005; 16: 2180-9.

36. Roger SD, McMahon LP, Clarkson A, et al. Effects of early and late intervention with epoetin alpha on left ventricular mass among patients with chronic kidney disease (stage 3 or 4): results of a randomized clinical trial. J Am Soc Nephrol 2004; 15: 148-56.

37. Levin A, Djurdjev O, Thompson C, et al. Canadian randomized trial of hemoglobin maintenance to prevent or delay left ventricular mass growth in patients with CKD. Am J Kidney Dis 2005; 46: 799-811.

38. Ritz E, Laville M, Bilous RW, et al. Target level for hemoglobin correction in patients with diabetes and CKD: primary results of the Anemia Correction in Diabetes (ACORD) Study. Am J Kidney Dis 2007; 49:194-207.

39. Drueke TB, Locatelli F, Clyne N, et al. Normalization of hemoglobin level in patients with chronic kidney disease and anemia. N Engl J Med 2006; 355: 2071-84.

40. Kalra PR, Bolger AP, Francis DP, et al. Effect of anemia on exercise tolerance in chronic heart failure in men. Am J Cardiol 2003; 91: 888-91.

41. Rocca $P$, Metra $M$, Nodari $S$, et al. L'anemia è associata con una ridotta capacità funzionale ed un'elevata incidenza d'ospedalizzazioni nei pazienti con insufficienza cardiaca. Ital Heart J 2003; 4(Suppl 6): 80S.

42. Metra M, Cannella G, La Canna G, Guaini T, Gaggiotti M, Movilli E, Dei Cas L. Improvement in exercise capacity after correction of anemia in patients with end-stage renal failure. Am J Cardiol 1991; 68: 1060-6.

43. Mancini DM, Katz SD, Lang CC, LaManca J, Hudaihed A, Androne AS. Effect of erythropoietin on exercise capacity in patients with moderate to severe chronic heart failure. Circulation 2003; 107: 294-9.

44. Ponikowski P, Anker SD, Szachniewicz J, et al. Effect of darbepoetin alfa on exercise tolerance in anemic patients with symptomatic chronic heart failure: a randomized, double-blind, placebo-controlled trial. J Am Coll Cardiol 2007; 49: 753-62.

45. Practice Guidelines for blood component therapy: a report by the Am Society of Anesthesiologists Task Force on Blood Component Therapy. Anesthesiology 1996; 84: 732-47.

46. Wu WC, Rathore SS, Wang Y, Radford MJ, Krumholz HM. Blood transfusion in elderly patients with acute myocardial infarction. N Engl J Med 2001; 334: 1230-6.

47. Herbert PC, Wells G, Blajchman MA, et al. A multicenter, randomized, controlled clinical trial of transfusion requirements in critical care: Critical Care Trials Group. N Engl J Med 1999; 340: 409-17.

48. Goodnough LT, Brecher ME, Kanter MH, Aubuchon JP. Transfusion medicine: first of two parts-blood transfusion. N Engl J Med 1999; 340: 438-47.

49. Coletta AP, Tin L, Loh PH, Clark AL, Cleland JG. Clinical trials update from the European Society of Cardiology heart failure meeting: TNT subgroup analysis, darbepoetin alfa, FERRIC-HF and KW-3902. Eur J Heart Fail 2006; 8: 547-9.

50. DaSilva L, Rodhe LE, Pereira-Barretto AC, et al. Rationale and design of the IRON-HF study: a randomized trial to assess the effects of iron supplementation in heart failure patients with anemia. J Cardiac Fail 2007;13:14-17.

51. Drueke T, Witko-Sarsat V, Massy Z et al. Iron therapy, advanced oxidation protein products, and carotid artery intima-media thickness in end-stage renal disease. Circulation 2002; 106: 2212-7.

52. Silverberg DS, Wexler D, Blum M, et al. The use of subcutaneous erythropoietin and intravenous iron for the treatment of the anemia of severe, resistant congestive heart failure improves cardiac and renal function and functional cardiac class, and markedly reduces hospitalizations. J Am Coll Cardiol 2000; 35: 1737-44.

53. Silverberg DS, Wexler D, Sheps D, et al. The effect of correction of mild anemia in severe, resistant congestive heart failure using subcutaneous erythropoietin and intravenous iron: a randomized controlled study. J Am Coll 
Cardiol 2001; 37: 1775-80.

54. Palazzuoli A, Silverberg D, lovine F, et al.Erythropoietin improves anemia exercise tolerance and renal function and reduces B-type natriuretic peptide and hospitalization in patients with heart failure and anemia. Am Heart $\mathrm{J}$ 2006;152: 1096.e9-15.

55. Abraham WT, Fisher WG, Smith Al, et al. Multicenter InSync Randomized Clinical Trial Evaluation Cardiac resynchronization in chronic heart failure. $\mathrm{N}$ Engl $\mathrm{J}$ Med 2002; 346: 1845-53.

56. van Veldhuisen DJ, McMurray JJ; RED-HF Executive Committee. Are erythropoietin stimulating proteins safe and efficacious in heart failure? Why we need an adequately powered randomised outcome trial. Eur $\mathrm{J}$ Heart Fail 2007; 9: 110-2.

57. Singh AK, Szczech L, Tang KL, et al. Correction of anemia with epoetin alfa in chronic kidney disease. $\mathrm{N}$ Engl J Med 2006; 355: 2085-98.

58. Drüeke TB, Locatelli F, Clyne N, et al. Normalization of haemoglobin level in patients with chronic kidney disease and anemia. N Engl J Med 2006; 355: 2071-84.

59. van Veldhuisen DJ, McMurray JJ; RED-HF Executive Committee. Are erythropoietin stimulating proteins safe and efficacious in heart failure? Why we need an adequately powered randomised outcome trial. Eur $\mathrm{J}$ Heart Fail 2007; 9: 110-2.

60. Fishbane S, Nissenson AR. The new FDA label for erythropoietin treatment: How does it affect hemoglobin target? Kidney Int advance online publication, 27 June 2007; doi:10.1038/sj.ki.5002401

61. Besarab A, Bolton WK, Browne JK, et al. The effects of normal as compared with low hematocrit values in patients with cardiac disease who are receiving hemodialysis and epoetin. N Engl JMed 1998; 339: 584-90.

62. Fuste B, Serradell M, Escolar G, Cases A, Mazzara R, Castillo R, Ordinas A, Diaz-Ricard M. Erythropoietin triggers a signaling pathway in endothelial cells and increas- es the thrombogenicity of their extra-cellular matrices in vitro. Thromb Haemost 2002; 88: 678-85.

63. Swedberg K, Cleland J, Dargie H, et al. Guidelines for the diagnosis and treatment of chronic heart failure: executive summary (update2005). The task force for the Diagnosis and Treatment of Chronic Heart Failure of European Society of Cardiology. Eur Heart J 2005; 26: 1115-40.

64. Hunt SA, Abraham WT, Chin MH, et al. ACC/AHA 2005 Guidelines Update for the Diagnosis and Management of Chronic Heart Failure in the Adult-Summary Article. A report of the Am College Cardiology/Am Heart Association Task Force on Pratice Guidelines. Circulation 2005; 112: 1825-52.

65. Parsa CJ, Matsumoto A, Kim J, et al. A novel protective effect of erythropoietin in the infarcted heart. J Clin Invest 2003; 112: 999-1007.

66. van der Meer P, Lipsic E, Henning $\mathrm{RH}$, et al. Erythropoietin induces neovascularization and improves cardiac function in rats with heart failure after myocardial infarction. $J$ Am Coll Cardiol 2005; 46: 125-33.

67. Lipsic E, Schoemaker RG, van der Meer P, Voors AA, van Veldhuisen DJ, van Gilst WH. Protective effects of erythropoietin in cardiac ischemia: from bench to bedside. J Am Coll Cardiol 2006; 48: 2161-7.

68. Westenbrink BD, Lipsic E, van der Meer P, et al. Erythropoietin improves cardiac function through endothelial progenitor cell and vascular endothelial growth factor mediated neovascularization. Eur Heart J 2007; [Epub ahead of print]

69. Leist M, Ghezzi P, Grasso G, Derivatives of erythropoietin that are tissue protective but not erythropoietic. Science 2004; 305(5681): 239-42.

70. Fiordaliso F, Chimenti S, Staszewsky L, et al. A nonerythropoietic derivative of erythropoietin protects the myocardium from ischemia-reperfusion injury. Proc Natl Acad Sci USA 2005; 102: 2046-51. 